\title{
Assessing Innovative Practices In Funding Entrepreneurship Education In Universities In Cross River State, Nigeria: Implications For Sustainable National Development
}

\author{
B. A. Akuegwu \\ Department of Educational Administration and Planning \\ University of Calabar, Calabar Nigeria \\ K. K. Uche \\ Department of Educational Administration and Planning \\ University of Calabar, Calabar Nigeria \\ D. E. Udo \\ Department of Educational Foundation \\ Cross River State College of Education , Akamkpa Nigeria
}

\begin{abstract}
This study assessed innovative practices in funding entrepreneurship education in universities in Cross River State, Nigeria and their implications for sustainable national development. Two research questions and one hypothesis were isolated to give direction to this investigation. Mixed methods research involving qualitative and quantitative techniques were adopted. 110 programme managers in the two universities constituted the population. All of them where used as sample. 13 innovative practices in funding entrepreneurship education were identified through interview involving programme managers. These innovative practices guided the researchers to construct an instrument titled "Innovative Practices in Funding Entrepreneurship Education Questionnaire (IPFEEQ)" which was used for data collection. Data collected were analysed statistically using Descriptive Statistics (Mean Rating) and Independent t-test statistical techniques. Results obtained indicated that entrepreneurship education programme managers have innovative practices with which they utilize in funding entrepreneurship education; programme managers are most effective in using marketing of products as innovative practice in funding entrepreneurship education. Ownership of universities does not significantly influence the utilization of innovative practices in funding entrepreneurship education. It was concluded that more efforts should be geared towards ensuring the success of innovative practices in funding entrepreneurship education given its efficacy in providing alternative funding.
\end{abstract}

Keywords: Innovative Funding Practices, Entrepreneurship Education, Universities.

\section{INTRODUCTION}

Entrepreneurship has become a veritable tool for tackling unemployment among the youths, especially university graduates. It engages them in lucrative business ventures as a means of providing self employment and employment for others. Apart from these, it unleashes creative instincts, wealth creation capacity, risk management ability and equips youths with profitable skills, competences, aptitudes, knowledge and experience to contribute meaningfully to individual and societal wellbeing and as well survive in a highly competitive and often harsh global economic environment. The manifestation of these entrepreneurship gains is a function 
of the availability of robust curriculum, which supposedly, is expected to specify the learning experiences (what is to be learned, how, when and where to learn it) and the calibre of personnel required to implement the curriculum. The effectiveness of the curriculum derives from the functionality of the education that manages it. Therefore, entrepreneurship curriculum cannot produce the desired result without a proper entrepreneurship education.

Entrepreneurship education is the structured formal conveyance of entrepreneurship competencies which in turn refers to the concepts, skills and mental awareness used by individuals during the process of starting and developing their growth oriented awareness [3]. Entrepreneurship education prepares young people to be accountable and innovative persons who become entrepreneurial thinkers and contribute to development and sustainable communities [8]. Furthermore, it provides youths the opportunity and experience to acquire entrepreneurial knowledge, skills and attitudes. It equips them with the ability and capacity to recognise opportunities, generate and create ideas, marshal and manage resources, establish and operate ventures and the critical thinking to make something out of nothing as well as managing and running ventures successfully. According to organisation for Economic Cooperative and Development, OECD, [10], the purpose of university entrepreneurship education is two fold - contributing to the creation and development of entrepreneurial attitudes and motivation to start-up a firm. Equally important is the development of skills needed to successfully run and grow a business venture.

However, no matter how good and laudable these purposes are, they cannot realize themselves. Realizing them to achieve the desired goals and objectives depends on the availability of funds. Nothing worthwhile in the education system, whether primary, secondary or tertiary can be achieved without funding. So is entrepreneurship education. Finance and funding are the major twin hurdles that entrepreneurship education has to cross. Educational programmes and university education specially have been facing under-funding [6]. Chronic under-funding and poor funding have become recurrent decimals in Nigerian education system, more pronounced in universities. They have been at the centre of face-offs between university lecturers and Federal or State Governments which has often culminated in strike actions with the attendant effect manifesting in closure of universities or elongation or suspension of academic calendars. Even at that, the challenge of poor funding has remained unabated. Academic Staff Union of Universities (ASUU) [4] noted recently with dismay that the present Government (Federal) rather reduced budgetary allocation to education to worsen the sector from 11 percent in 2013, 12 percent in 2014, and 11 percent in 2015 to 8 percent in 2016 budget. The implication is that academic programmes such as entrepreneurship education will not be able to make the necessary impact in creating employment for youths as a way of tackling unemployment and other social and societal challenges.

According to Scholars Works [11], availability of funds in any education programme is a critical factor in achieving functionality of such programme. The unavailability of funds to our schools makes the cry for entrepreneurship education to be on papers than practices. That is, no matter how we express the quest for and desirability of entrepreneurship education, no tangible results can be achieved without adequate funding. Funding mainly is the engine that propels entrepreneurship education to resounding success. Universities are struggling to meet increased demand for quality education and to adapt to transformations in the global knowledge economy. At same time, they are dealing with the consequences of economic meltdown. This has resulted to inevitable cuts in government subventions, which means that public universities in Nigeria face increased pressure to take on added responsibilities for their long term financial sustainability [9]. The cut in government subventions to universities means that they have to grapple with under-funding, which affects negatively the effective functioning 
of programmes like entrepreneurship education. Consequently, universities funding of entrepreneurship education has remained infinitesimal, unable to achieve significant results. This underscores the need for programme managers of entrepreneurship education to seek for and adopt innovative practices in funding entrepreneurship education in universities.

Innovative has to do with introducing new ideas which are original and being creative in thinking. Innovative practices on the other hand are about looking beyond current activities with a view to identifying the great ideas of tomorrow and putting them into practice. Funding is the act of making funds available for a particular purpose, in this case running entrepreneurship education. Innovative practices in funding entrepreneurship education is looking beyond the current funding provisions with a view to identifying and putting into practice other workable means of generating additional funds to run entrepreneurship education programme effectively. It is the quest for identifying these innovative practices in funding entrepreneurship education by programme managers in universities and how effective they are that constituted the main thrust for this paper. Ownership of universities as used in this paper means the body that established, run, fund and control universities. There are two main bodies that own universities in Nigeria as used in this study - Federal and State Governments.

\section{STATEMENT OF THE PROBLEM}

Poor and under-funding have been major bottlenecks internal managers of university education have been contending with over the years. It has its spill over effect on entrepreneurship education. As it is, poor funding has rendered entrepreneurship education unable to provide solution to unemployment challenges. Despite the introduction and running of entrepreneurship education in universities, unemployment among the youths remains unabated. Even at that, staff development and procurement of requisite facilities for entrepreneurship education have been lacking due o paucity of funds. Apart from this, studies in entrepreneurship education have not been targeted at innovative practices in funding it in universities particularly in Cross River State. This is what this study seeks to address and so, the problem of this study is: what are innovative practices in funding entrepreneurship education in universities in Cross River State and how effective are they in achieving the desired results?

\section{RESEARCH QUESTIONS}

What are the innovative practices adopted by programme managers in funding entrepreneurship education in universities in Cross River State?

Which innovative practice is the most effective in funding entrepreneurship education in universities in Cross River State?

\section{HYPOTHESIS}

There is no significant influence of ownership of universities in their utilization of innovative practices in funding entrepreneurship education.

\section{LITERATURE REVIEW}

Studies targeted at innovative practices in funding entrepreneurship education have not been particularistic, but dwelt on funding entrepreneurship education generally. However, reviews presented are related and relevant to this study.

Ogundele and Bello [7] noted in their study that if effective entrepreneurship education is to be provided and enhanced, adequate funds must be available. They found that there is positive 
significant relationship between the amount of funds generated and entrepreneurship. It therefore follows that the more funds are generated, the more the development of entrepreneurship education and the less the funds are generated, the less the development of entrepreneurship education. Therefore, the development of entrepreneurship education is tied to the availability of funds. Similarly, they found a significant positive relationship between the expenditure pattern and the development of entrepreneurship education. This implies that it is the expenditure pattern that really matters in the development of entrepreneurship education. Judicious and effective expenditure pattern is likely to result to the development of entrepreneurship education. On the contrary, reckless expenditure pattern has the likelihood to result to the retardation of entrepreneurship education. This calls for prioritization in the expenditure pattern if the development of entrepreneurship education is to be achieved. Thus, funds may be available; the expenditure pattern may not produce the desired result. It is only when the available funds are properly expended that tangible results can be achieved in entrepreneurship education.

Zhou and Haixia [12] reported that in China, most universities maintain an entrepreneurship fund to evaluate students' business plan and finance those that show special promise. This helps in enhancing the development and administration of entrepreneurship education. However, this practice is conspicuously lacking in Nigerian universities. Thus, innovative practices adopted by some countries in ensuring effective funding of their entrepreneurship education programme are yet to find their way to universities entrepreneurship education in Nigeria.

According to Agbonlahor [1], the infrastructure needed to deliver quality and practical oriented entrepreneurship education requires huge investment in capital. Inadequate funding is indicted in the poor infrastructural support needed to drive quality delivery of entrepreneurship education. The lack of supportive infrastructure and infrastructural failures are capable of resulting to high transaction costs which makes delivery of entrepreneurship education very expensive and inefficient.

For effective entrepreneurship education programme to be achieved and enhanced in tertiary institutions, adequate funds should be sourced and utilized for establishing procurement and installation of the necessary equipments [7]. In support, Scholars Works [11] pointed out that well funded entrepreneurship education programme will no doubt equip the schools with adequate facilities needed for efficiency of the subject and achieving the stipulated objectives of entrepreneurship education. Availability of funds, therefore, is the key to the provision of adequate facilities for effective teaching of entrepreneurship education. Inadequate funding has the capability to stagnate the implementation of entrepreneurship education curricula. This is corroborated by Odiba [5] who posited that poor funding results to inadequate provision of infrastructural facilities. Accordingly, poor funding and inadequate provision of resources to cope with the demands of entrepreneurship education have led to inadequate provision of facilities for effective teaching of the course.

From the reviews so far, it can be deduced that poor funding has been at the root of poor delivery of entrepreneurship education, and consequently, the attendant unemployment problems. Funding is first and foremost at the heart of quality entrepreneurship education delivery. Every other requirement for effective entrepreneurship education such as qualified personnel, learning environment, quality facilities and well-stocked library depends on the availability of funds. It is on this premise that it has become imperative for programme managers to think out of the box with a view to identifying and utilizing innovative practices to fund entrepreneurship education. 


\section{METHODS}

This research took place in Cross River State, Nigeria. It is one of the states that constitute south-south geo-political zone of Nigeria and the oil-rich Niger Delta Region, lying on the coastal axis. Its political and economic capital is Calabar. Two universities are located in the state - one conventional (Federal), the other technological (specialist) (State). Mixed methods research involving qualitative and quantitative techniques were used. Qualitative techniques comprising interview approach was employed to ascertain innovative practices in funding entrepreneurship education. 110 Entrepreneurship Education Programme Managers in the 2 universities made up of 2 Directors of Entrepreneurship Development Centres (EDCs), 4 Deputy Directors, 58 Co-ordinators of various entrepreneurship ventures, 2 Finance Officers, 22 Faculty Representatives and 22 Desk Officers were interviewed and they came up with 13 innovative practices in funding entrepreneurship education. These programme managers are involved in one way or the other in generating funds for entrepreneurship education. This 110 programme managers constituted the population, which was purposively constituted into the sample.

The researchers constructed an instrument titled "Innovative Practices in Funding Entrepreneurship Education Questionnaire (IPFEEQ)", on the 13 identified innovative practices to generate quantitative data. Section A of the instrument (IPFEEQ) contained 1 demographic data, while section $B$, arranged on 5-point rating scale had 65 items, 5 of which measured each of the 13 innovative practices. The instrument was face-validated by 2 experts in Entrepreneurship Education and 2 experts in measurement and evaluation. A trial test using 35 programme managers from another university outside the study area was conducted. Cronbach Alpha method was used to establish the internal consistency of the instrument. Coefficients obtained ranged from .86 to .92 , which is an indication that the instrument was reliable in achieving the objectives of this study. The administration of the instrument was carried out by the researchers and 2 trained research assistants, who were trained on how to approach subjects with a view to getting them respond objectively to the instrument. This measure produced a 100 percent returns rate on the instrument. Descriptive statistics (X and SD) and Independent t-test statistical techniques were used to analyse the data collected. Summaries of the results were presented in tables.

\section{Research Questions}

\section{RESULTS}

What are the innovative practices adopted by programme managers in funding entrepreneurship education in universities in Cross River State? The variable in this research question is innovative practices adopted by programme managers in funding entrepreneurship education. Interview conducted on programme managers gave rise to 13 innovative practices which are presented in table 1. 


\section{Table 1:}

Innovative Practices identified

$\mathrm{N}=13$

Registration Fees

Bank Loans

Sales of Publications

Marketing of Products

Alumni Donations

Dividends from Shares

Consultancy Services

Part-time Programme (Sandwich)

Crowd Sourcing

Equipment Hiring/Leasing

Sales of Admission Forms

Hiring of Academic Gowns

Commercializing of Research Findings

Which innovative practice is the most effective in funding entrepreneurship education in universities in Cross River State? The variable in this research question is innovative practices in funding entrepreneurship education. Descriptive statistics ( $X$ and SD) are used to provide answer to this question. Summaries of the results are presented in table 2 .

Table 2

Summaries of Mean $\overline{(X)}$ and Standard Deviation (SD) of Programme Managers' Effectiveness in Utilizing Innovative Practices in Funding Entrepreneurship Education.

\begin{tabular}{lccc} 
& $\mathrm{N}=110$ & & \\
\hline Variables & $\mathrm{X}$ & $\mathrm{SD}$ & Rank \\
\hline Marketing of Products & 16.79 & 2.63 & $1^{\text {st }}$ \\
Sales of Publications & 16.31 & 2.88 & $2^{\text {nd }}$ \\
Consultancy Services & 15.73 & 2.78 & $3^{\text {rd }}$ \\
Crowd Sourcing & 15.31 & 3.35 & $4^{\text {th }}$ \\
Equipment Hiring/Leasing & 15.29 & 3.56 & $5^{\text {th }}$ \\
Registration Fees & 14.17 & 3.57 & $6^{\text {th }}$ \\
Sales of Admission Forms & 13.95 & 2.79 & $7^{\text {th }}$ \\
Hiring of Academic Gowns & 13.70 & 2.51 & $8^{\text {th }}$ \\
Part-time Programme (Sandwich) & 13.35 & 2.41 & $9^{\text {th }}$ \\
Dividends from Shares & 13.10 & 2.69 & $10^{\text {th }}$ \\
Donations from Alumni & 13.09 & 2.88 & $11^{\text {th }}$ \\
Commercializing of Research Findings & 12.95 & 3.08 & $12^{\text {th }}$ \\
Bank Loans & 12.45 & 3.02 & $13^{\text {th }}$ \\
\hline
\end{tabular}

Summaries of the results presented in table 2 disclosed the effectiveness of the innovative practices in funding entrepreneurship education according to ranks. In the first position is marketing of products, which shows that programme managers are most effective in using it as innovative practice in funding entrepreneurship education $\overline{(X}=16.79)$. Next is sales of publications $\overline{(X}=16.31)$, followed by consultancy services $(\bar{X}=15.73)$. Placed fourth is crowd sourcing $\overline{(X}=15.31)$, followed by equipment hiring/leasing $\overline{(X}=15.29)$. Ranked sixth is registration fees $\overline{(X}=14.17)$ with sales of admission forms following it $\overline{(X}=13.95)$. Hiring of academic gowns $(\bar{X}=13.70)$ is placed in the eighth position, followed by part-time programme (sandwich) $\overline{(X}=13.35)$ while dividends from shares $\overline{(X}=13.10)$ is next in the tenth position. In the eleventh position is donations from alumni $(\mathrm{X}=13.09)$, followed by commercializing of research findings $(\bar{X}=12.95)$, while bank loans appeared in the rear position $(X=12.45)$.

From these results, it can be deduced that innovative funding of entrepreneurship education by programme managers comes mostly from marketing of products, while they are least effective in funding entrepreneurship education with bank loans. 


\section{Hypothesis}

There is no significant influence of ownership of universities on their utilization of innovative practices in funding entrepreneurship education. Independent variables are ownership of universities, while dependent variable is utilization of innovative practices in funding entrepreneurship education. Independent t-test statistical analysis is used to compare the mean scores from programme managers in the two universities studied. Summaries of the results are presented in table 3.

Table 3

Summaries of Independent t-test statistical analysis of the influence of ownership of universities on utilization of innovative practices in funding entrepreneurship education

Ownership of Universities

\begin{tabular}{lrrrrr}
\hline & \multicolumn{3}{c}{ Ownership of Universities } & & \\
& Federal, & $\mathrm{N}=70$ & State, $\mathrm{N}=40$ & & \\
\hline Variables & $\overline{\mathrm{X}}$ & $\mathrm{SD}$ & $\mathrm{X}$ & $\mathrm{SD}$ & $\mathrm{t}$ \\
\hline Marketing of Products & 16.81 & 2.55 & 16.75 & 2.79 .123 \\
Equipment Hiring/Leasing & 15.17 & 3.65 & 15.50 & 3.36 & -.463 \\
Consultancy Services & 15.74 & 2.98 & 15.70 & 2.43 .077 \\
Bank Loans & 12.46 & 3.03 & 12.43 & 3.02 .054 \\
Sales of Admission Forms & 13.97 & 2.85 & 13.93 & 2.72 .084 \\
Sales of Publications & 16.56 & 2.85 & 15.88 & 2.92 & 1.196 \\
Registration Fees & 13.81 & 3.49 & 14.80 & $3.66-1.400$ \\
Crowd Sourcing & 15.53 & 3.43 & 14.93 & 3.21 .909 \\
Hiring of Academic Gowns & 13.77 & 2.57 & 13.58 & 2.45 .393 \\
Commercializing of Research Findings & 13.01 & 2.98 & 12.85 & 3.28 .268 \\
Donations from Alumni & 13.03 & 2.56 & 13.20 & 3.40 & -.299 \\
Dividends from Shares & 13.04 & 2.61 & 13.20 & $2.86-.294$ \\
Part-time Programme (Sandwich) & 13.66 & 2.30 & 12.83 & 2.541 .756 \\
\hline
\end{tabular}

$\mathrm{p}>.05 ; \mathrm{df}=108 ;$ critical $\mathrm{t}$-value $=1.980$

Summaries of the results presented in table 3 indicated that the calculated t-values were found to be less than the critical t-value of 1.980 at .05 level of significance and 108 degrees of freedom. Specifically the calculated $t$-values are: Marketing of products $(t=.123, p>.05)$, equipment hiring/leasing $(\mathrm{t}=-.463, \mathrm{p}>.05)$, consultancy services $(\mathrm{t}=.077, \mathrm{p}>.05)$, bank loan $(\mathrm{t}$ $=.054, \mathrm{p}>.05)$, sales of admission forms $(\mathrm{t}=.084, \mathrm{p}>.05)$, sales of publications $(\mathrm{t}=1.196, \mathrm{p}$ $>.05)$, registration fees $(t=1.400, p>.05)$, crowd sourcing $(t=.909, p>.05)$, hiring of academic gowns $(t=.393, p>.05)$, commercializing of research findings $(t=.268, p>.05)$, donations from alumni $(t=-.299, p>.05)$, dividends from shares $(t=-.294, p>.05)$ and part-time programme (sandwich) $(\mathrm{t}=1.756, \mathrm{p}>$.05). With this result, the null hypothesis was not rejected. Therefore, there is no significant influence of ownership of universities on their utilization of innovative practices in funding entrepreneurship education.

Further observation of the results revealed that programme managers from Federal university had higher mean values in 9 of the innovative funding practices studied. Conversely, State university programme managers had higher mean values in 4 of the innovative funding practices. Statistical comparison of the mean values from the two categories of programme managers using Independent t-test yielded a no significant result, although Federal university had an edge over State University in their mean values.

\section{DISCUSSION OF FINDINGS}

The first research question sought to find out the innovative practices adopted by programme managers in funding entrepreneurship education. Interview on this subject conducted on programme managers yielded 13 innovative practices. These include: Marketing of products, consultancy services, equipment hiring/leasing, sales of publications, registration fees, sales of 
admission forms, crowd sourcing, hiring of academic gowns, commercializing of research findings, donations from alumni, bank loans, dividends from shares and part-time programme (sandwich). They explained how they raise funds through these innovative practices.

Marketing Products: Under this innovative practice, programme managers sell their products such as detergents, soaps, snacks, cloths, sachet water, vegetable oil, shoes, fishes, snails amongst others. The money generated is ploughed into entrepreneurship education to keep it running.

Consultancy services are the services provided for prospective entrepreneurs who seek professional advice on how to establish and run entrepreneurship ventures successfully. This attracts some fees from the prospective entrepreneurs.

Equipment hiring/leasing: This involves hiring or leasing out some equipment to people such as photographic, video coverage, sewing machines, interior decoration equipment amongst others. Funds generated from these are used to run entrepreneurship education. Sales of publications are where funds are generated from the sales of books, journals and convocation programmes or brochures. Registration fees involve money paid by new students or entrants of the programme to register for their teaching and other services. Sales of admission forms are funds generated from admission forms purchased by prospective students or candidates for the entrepreneurship education programme.

Crowd sourcing involves the purchase of shares by university staff and students from the Entrepreneurship Development Centres. It is an internal arrangement meant for the benefit of university community. Hiring of academic gowns comes during convocation ceremonies. Graduates pay some money to hire academic gowns, which they return after the ceremonies and in some cases part of the monies are refunded back to them. Commercialising of research findings is where research findings from Entrepreneurship Development Centres are made available to members of the public for a fee. For instance, best practices discovered through research from such ventures as snail and fisheries farming, water packaging, food processing, animal husbandry, bakery etc are made available to entrepreneurs engaged in them for a fee.

Donations from alumni are funds generated through free will donation from graduates of the programme who have left the universities and are engaged in one venture or the other. Usually, EDCs organise a programme tagged: Home Coming where successful alumni are invited to be honoured as a result of their outstanding performances in their respective ventures and contributions to societal and national development. Of course, this honour is accepted with donations to the well being of EDCs. Bank loan is where EDCs obtain loans from commercial banks to fund their activities and programmes. Dividends from shares are funds generated from dividends accrued to EDCs from shares they held at commercial banks. Part-time programmes (sandwich): EDCs organise sandwich programmes during long vacations for candidates and students and fees paid by them for such services are utilized in running entrepreneurship education.

These innovative practices are avenues in generating additional funds to run entrepreneurship education. This is in line with the views of Ogundele and Bello [7] that effective entrepreneurship education in tertiary institutions requires sourcing and utilizing adequate funds.

Results of research question 2 revealed that programme managers of entrepreneurship education are most effective in utilizing marketing of products most effectively as innovative 
practice in funding entrepreneurship education and least effective in utilizing bank loans for the same purpose. This implies that programme managers expend much efforts, energy and resources in marketing of their products more than any other innovative practice in funding entrepreneurship education. The reason for this finding might be explained that marketing of products yield quick and easy funds because the products involved are in high demands on daily basis. They are always patronised by staff, students and members of the public to guarantee steady income, as such programme managers ensure that these products are always in stock so as to generate enough funds to manage their entrepreneurship education. This finding is corroborated by the results of Ogundele and Bello's [7] research that a positive significant relationship exists between the amount of funds generated and the development of entrepreneurship education.

Results of the hypothesis indicated that there is no significant influence of ownership of universities on their utilization of innovative practices in funding entrepreneurship education. This means that the way and manner innovative practices are utilized in funding entrepreneurship education is the same in the two universities studied. A plausible explanation for this finding might be that the universities have the same objectives for entrepreneurship education and operate the same policy in running it. So, what is found in one university might be replicated in the other whether Federal or State owned. Findings of Akuegwu and Nwi-ue [2] that universities, irrespective of type or ownership operate the same policies in running their programmes and in appointments of personnel to positions, is in consonance with this result. It therefore follows that what one university does with regards to managing her entrepreneurship education is what her counterpart also do in order to achieve the same purpose.

\section{IMPLICATIONS FOR SUSTAINABLE NATIONAL DEVELOPMENT.}

Given the importance of entrepreneurship education to national development, this study's finding has some implications. These are articulated thus:

By fashioning out avenues to raise additional funds to run entrepreneurship education implies that programme managers are not resting in their oars and bemoaning infinitesimal amount of funds available from university authority. This has demonstrated tremendous commitment among them to ensure the survival and achievement of the goals of entrepreneurship education. By so doing, they guarantee the acquisition of veritable entrepreneurship skills among students with which they can provide self-employment for themselves and others upon their graduation. This contributes immensely towards achieving present and future national development goals.

This study revealed that entrepreneurship education programme managers are most effective in using marketing of products as innovative practices in funding entrepreneurship education. This implies that they expend much time, energy and resources on marketing of their products whose nature guarantee quick and steady income. With this marketing of products, the funds generated there from can be used to keep entrepreneurship education afloat. Availability of funds means that entrepreneurship education can live up to the expectation of equipping students with skills for survival, and so contribute towards national development both presently and in future.

The no significant influence of ownership of universities on their utilization of innovative practices in funding entrepreneurship education implies that innovative practices in funding entrepreneurship education are not confined to ownership of universities. The two universities studied utilize innovative practices the same way, which means they work assiduously towards the success of entrepreneurship education the same way. With their efforts and commitment, 
entrepreneurship education is likely to be used to solve the problems of unemployment in the state, and so contribute to national development presently and in future.

\section{CONCLUSION}

From the findings of this study, it can be concluded that entrepreneurship education programme managers have innovative practices with which they rely on in funding entrepreneurship education. They are most effective in using marketing of products as innovative practice in funding entrepreneurship education. Ownership of universities does not significantly influence the utilization of innovative practices in funding entrepreneurship education. Therefore, despite the fact that innovative practices are evolved in funding entrepreneurship education, not all of them produce the same results, but they achieve the same purpose in universities.

\section{RECOMMENDATIONS}

From the findings of this study, it is recommended that:

More efforts should be geared towards ensuring the success of innovative practices in funding entrepreneurship education given its efficacy in providing alternative funding.

Equal time, efforts and resources should be committed on all the identified innovative practices in funding entrepreneurship education, especially those domiciled within the universities. This may reduce the pressure and over dependence on marketing of products.

\section{References}

Agbonlahor, A. A. (2016). Challenges of entrepreneurial education in Nigerian universities: Towards a repositioning for impact. Journal of Education and Social Research, 6(1), 208 - 214.

Akuegwu, B. A. \& Nwi-ue, F. D. (2017). Providing academic leadership in universities in Cross River State, Nigeria: Assessment of departmental heads' effectiveness. Asian Journal of Education and Training, 3(1), 18 - 24.

Alberti, F., Sciascia, S. \& Poli, A. (2004). Entrepreneurship education: Note on an ongoing debate. Proceedings of the $14^{\text {th }}$ Annual International Entrepreneurship Conference, University of Napoli, Federico II, Italy, $4-7$ July.

Academic Staff Union of Universities (ASUU) (2016). Poor funding killing education in Nigeria. Retrieved from http://www.pulse.ng

Odiba, I. A. (2011). Rethinking teacher education in Nigeria: Implication for manpower development. In E. A. Arubayi, N. E. Akpotu \& E. P. Oghuvbu (Eds), Education and training for entrepreneurship (pp. 363 - 368). Abraka: NAEAP.

Odiba, I. A. \& Baba, P. A. (2013). Entrepreneurship education in Nigeria universities: A recipe for national development in the $21^{\text {st }}$ Century. Journal of Education and Practice, 4(20), 36 - 39.

Ogundele, M. O. \& Bello, Y. (2014). Financing entrepreneurship education programme in Kwara State tertiary institutions, Nigeria. European Journal of Academic Essays, 1(2), 29 - 34.

Okolie, U. C., Elom, E. N., Ituma, A., Opara, P. N., Ukwa, N. J., Inyiagu,, E. J. \& Ndem, J. (2014). Influence of entrepreneurship education on students attaining development awareness and skills acquisition in Nigeria. IOSR Journal of Research and Methods in Education, 4(3), 37 - 44.

Omonijo, D. O., Uche, O. O. C., Rotimi, O. A. \& Nwadialor, K. L. (2014). Social analysis of moral malpractice challenging education sector in Nigeria. British Journal of Education, Society and Behavioural Science, 4(7), 965 986.

Organisation for Economic Cooperation and Development (OECD)(2010). University entrepreneurship support: Policy issues, good practices and recommendations. Retrieved from http://www.oecd.org/edu/imhe/46588578.pdf

Scholar Works (2016). Challenges of entrepreneurship education in Nigeria. Retrieved from http://www.scholarworks.com

Zhou, M. \& Haixia, Xu (2012). A review of entrepreneurship education for college students in China. Administrative Science, 2, 82 - 98. 